\title{
Recovery of Acetylcholinesterase Activity in the Common Carp (Cyprinus carpio L.) After Inhibition by Organophosphate and Carbamate Compounds
}

\author{
Dembele K, Haubruge E, Gaspar C \\ Gembloux Agricultural University, 2, Passage des Deportes, B-5030 Gembloux, Belgium
}

Organophosphate (OP) and carbamate (C) have replaced organochlorine pesticides because of their rapid breakdown in water and their low environmental persistence. However, these insecticides used in intensive agricultural production can reach the aquatic environment either via seepage of chemicals from the soil or directly due to the spraying against pests (Castillo et al. 1997). These compounds may become concentrated in the organs of aquatic organisms, especially those at the top of the food chain. The main mechanism of action of organophosphate and carbamate insecticides involves the inhibition of cholinesterase $(\mathrm{ChE})$.

There are two distinct types of enzymes capable of acetylcholine hydrolysis. The acetylcholinesterase or "true cholinesterase" (AChE EC.3.1.1.8) predominantly associated with nervous tissue and erythrocytes, and the pseudo cholinesterase (ChE EC: 3.1 .1 .7 ) which is found in the serum, muscle and ganglia (Fossi et al. 1995; Harel et al. 1992; Vigny et al. 1978). These two enzymes, AChE and ChE can be distinguished not only by their distribution but also by their substrate specificity and their sensitivity to certain selective inhibitors (Augustisson and Nachmanshon 1949; Davison 1955; Toutant et al. 1985; Vigny et al. 1978). Both AChE and ChE are inhibited by eserine but only AChE is inhibited by 1.5-bis(4-allyl dimethyl amino phenyl)pentan-3-one dibromide (BW284C51) and by an excess of substrate, for example acetylthiocholine chloride (ACh) (Augustisson and Nachmanshon 1949; Vigny et al. 1978). These enzymes may be soluble, linked to the basal lamina via a collagen tail or to membrane via a glycolipid or via a hydrophobic peptide (Bon et al. 1979; Massoulie and Bon 1982).

The toxicity of OP and C insecticides toward AChE has been extensively studied both in insects and vertebrates (Bocquene et al. 1995; Coppage and Mathews 1974; Haubruge and Toutant 1997; Sharma et al. 1993). The accepted mode of action of these insecticides is to phosphorylate or carbamilate AChE enzyme (Fleming and Grue 1981). This results in the increase of acetylcholine levels at the nerve synapse causing continual stimulation of the fibers and eventual failure of nerves to repolarize. Moreover, some pesticides are used in fish farming. Those applications cause great damage to fish populations (Bocquene et al. 1995). Acetylcholinesterase, the primary enzymatic target of OP and C is commonly used to detect their impacts (Bastos et al. 1991; Fossi et al. 1995; Westlake et al. 1981a; Westlake et al. 1981b). In order to use AChE as an insecticide pollution biomarker, it is necessary to characterise this enzyme. We are interested in validating in vitro methods, which will predict in vivo toxicity. We study teleostean brain AChE, particularly in common carp, because of its great geographical distribution throughout the world (Billard 1995). Previous investigators have characterised AChE in common carp using different extraction techniques and inhibitors (Szabo et al. 1992; Szegletes et al. 1995). The objectives of this paper were: firstly to extend the observations of Szabo et al. (1992) by investigating the common carp brain AChE, secondly to determine the type of inhibition induced by carbofuran (C) in chlorfenvinphos (OP) on the common carp brain AChE, and finally to determine the in vivo required time for the recovery of brain AChE activity of the common carp after inhibition by these two insecticides.

\section{Materials and methods}

Group of four hundred one year-old fish of $6-8 \mathrm{~cm}$ length were obtained from an industrial fish farm (Piscimeuse, Thiange; Belgium) and were acclimatized in a $6 \times 3 \times 0.75 \mathrm{~m}$ aquarium in our experimental fish farm. During acclimatization (12 days) and after the four days of exposure the fish were fed every $72 \mathrm{hr}$ with Trouvit compound (Trouw, Fontaine - les -Vervins: France). Water temperature and aeration were kept at $8^{\circ} \mathrm{C}+2^{\circ} \mathrm{C}$ at $0.66 \pm 0.1 \mathrm{~g} / \mathrm{L}$ of oxygen respectively. Chlorfenvinphos (2-chloro-1-(2,4-dichlorophenyl)-vinyl diethyl phosphate (97\% purity) an carbofuran (2.3-dihydro-2,2-dimethyl-7 benzo-furanol methylcarbamate) (99\% purity) were purchased from Riedel-de-Haen. Curater (carbofuran) (400g/L)) and Birlan ${ }^{\circledR}$ (chlorfenvinphos) $(240 \mathrm{~g} / \mathrm{L})$ were purchased from Cyanamid and Bayer respectively. Physostigmine (eserine), 1.5-bis(4-allyl dimethyl amino phenyl)pentan-3-one dibromide (BW284C51); 
5,5'-dithiobis-(2-nitrobenzoic acid) (DTNB) and the substrate acetylthiocholine chloride (ACh) were purchased from Sigma Chemical Co. Bovin serum albumin (BSA) used for the determination of protein quantity was purchased from Bio Rad.

Carbofuran, chlorfenvinphos and Birlan ${ }^{\circledR}$ were solubilized in ethanol, the other chemicals were solubilized in distillate water.

At the time of sampling, the animals were sacrificed and the whole brain was collected in a centrifuge tube. The enzyme was solubilized in several steps: the soluble forms were first extracted in $10 \mathrm{~mL}$ of low saline buffer (LSS: $50 \mathrm{mM} \mathrm{MgCl} 2,10 \mathrm{mM}$ Tris-HCl pH 7.0, and $1 \mathrm{mg} / \mathrm{mL}$ bacitracin). The pellet obtained after centrifugation $\left(18,000 \times \mathrm{g}, 15 \mathrm{~min}, 4^{\circ} \mathrm{C}\right)$ was then homogenated and centrifuged in saline buffer (HSS: $50 \mathrm{mM} \mathrm{HgCl} 2,10 \mathrm{mM}$ Tris- $\mathrm{HCl}(\mathrm{pH} 7,0)$ bacitracin lmg/mL; $1 \mathrm{M} \mathrm{NaCl})(18,000 \times \mathrm{g}, 15$ $\min , 4^{\circ} \mathrm{C}$ ). The pellet obtained after centrifugation in saline buffer was homogenated in saline buffer containing 2\% Triton X-100 (DSS) which solubulized all the rest of the cholinesterase.

Protein determination was performed using the original Lowry method (Lowry et al. 1951). Twenty five microliters of supernatant were incubated with $1125 \mu \mathrm{L}$ of folin reagent $(125 \mu \mathrm{L}$ of $\mathrm{A}$ and $1000 \mu \mathrm{L}$ of B). The content was then mixed and after $15 \mathrm{~min}$ of incubation the absorbance was read at $750 \mathrm{~nm}$ using a Shimadzu $160 \mathrm{~A}$ UV spectrophotometer at $25^{\circ} \mathrm{C}$. Brain AChE activity determination was carried out using the method of Ellman et al. (1961) modified as follows: the supernatant $(100 \mu \mathrm{L})$ was added to a test tube $(1.5 \mathrm{~mL})$ containing $880 \mu \mathrm{L}$ of $0.1 \mathrm{M}$ phosphate buffer $(\mathrm{pH} 8.5), 10 \mu \mathrm{L}$ of $100 \mathrm{mM}$ DTNB and $10 \mu \mathrm{L}$ of $0.1 \mathrm{M}$ acetylthiocholine chloride. The content was then mixed and the absorbance read at $412 \mathrm{~nm}$ continuously for $1 \mathrm{~min}$.

Inhibitor specificity was studied as follows: the supernatant of each extraction was preincubated with inhibitor (eserine or BW284C51) at $25^{\circ} \mathrm{C}$ for $2 \mathrm{~min}$. After this period, the substrate and dye DTNB were added to the mixture, and the remaining activity of $\mathrm{AChE}$ was determined after further incubation for $1 \mathrm{~min}$ at $25^{\circ} \mathrm{C} ; \mathrm{pH} 8.5$.

Effect of substrate concentration on AChE activity and kinetic studies were made using acetylthiocholine chloride as substrate. The initial velocity for kinetic studies was determined after AChE was incubated with increasing ACh concentration from 0.1 to $5 \mathrm{M}$ for $1 \mathrm{~min}$ at $25^{\circ} \mathrm{C} \mathrm{pH} \mathrm{8.5.}$ Michaelis constant $\left(\mathrm{K}_{\mathrm{m}}\right)$ and maximal velocity $\left(\mathrm{V}_{\max }\right)$ were determined by Lineweaver - Burk transformation (Zhu and Brindlay 1992).

We also studied the type of inhibition induced by carbofuran and chlorfenvinphos, for that: three concentrations of both carbofuran $\left(0,2\right.$, and $\left.4 \times 10^{-7} \mathrm{M}\right)$ and chlorfenvinphos $\left(0,9\right.$ and $\left.18 \times 10^{-6} \mathrm{M}\right)$ were presented to the reaction systems with varied substrate concentrations. The AChE activity was determined by the method of Ellman et al. (1961) modified, and the results were represented by the method of Hanes-Woolf (Segel 1975).

The experiment performed to examine the recovery of AChE activity was designed as follows. Thirty fish were exposed to Birlan ${ }^{\circledR}$ (chlorfenvinphos) $(0.24 \mathrm{ppb})$ and Curater $\AA$ (carbofuran) ( $\left.3 \mathrm{ppb}\right)$ respectively diluted in ethanol and water. Control group was performed with ethanol for 4 days in static condition. Activity of brain AChE was then determined to assess depression after the 4 days. After the exposure period, fish were transferred to a free insecticide aquarium. The treated groups and control were then sampled at 1,2, 8, and 15 days postexposure.

Specific activities were analysed by oneway analysis of variance followed by a linear regression test and achieved by the test of Tukey (Dagnelie 1975). All the tests were considered at the significant level 0.05 .

\section{Results and discussion}

The first and second extractions without Triton X-100 retained 30.50 and $59.37 \%$ of total activity respectively. These two extracts were considered as the soluble fraction. The third extraction with $2 \%$ of Triton X-100 retained $12.77 \%$ of the total activity. This fraction was the membrane bound enzyme. The results obtained here were in close agreement with those of Szabo et al. (1992), who stated that the soluble fraction represented the greatest part of the common carp brain ChE.

ChE was extracted with low salinity buffer (LSS), high salinity buffer (HSS) and high salinity buffer with $2 \%$ Triton $\mathrm{X}-100$ (DSS). The preincubation took $2 \mathrm{~min}$ at $25^{\circ} \mathrm{C} \mathrm{pH} \mathrm{8.5.}$

Eserine and BW284C51 were used in vitro to assess ChE specificity. They were effective inhibitors of the enzyme. Eserine is known to be an inhibitor of both AChE and ChE; (Sylver, 1974). Our results showed that only about $62 \%$ of the crude homogenate of the common carp brain extract in LSS fraction were cholinesterase but more than $85 \%$ of the crude homogenate extracted with HSS and DSS were cholinesterase (Table 1). 
In similar conditions to our experiment, a sample of rat serum, which is known to contain both AChE and ChE, assayed in the presence of BW284C51 revealed a biphasic inhibition curve (Sine et al. 1992; Sylver 1974; Vigny et al. 1978). On the contrary, we observed that all inhibition curves were monophasic (Figure $1 \mathrm{~A}$ and $\mathrm{B}$ ).

The hydrolysis of acetylthiocholine chloride is inhibited by BW284C51 at $10^{-5} \mathrm{M}$ for both soluble and membrane bound forms. The percent of inhibition of the AChE activities observed in the presence of $10^{-5}$ M BW284C51 (Table 1)

suggested that the contribution of AChE to ACh hydrolysis was $92.25 \%, 95.09 \%$, and $97.33 \%$ for LSS, HSS and DSS respectively.

The conclusion above was confirmed by the kinetic studies, in which, in the presence of increasing concentrations of $\mathrm{ACh}$, the activity of both soluble and membrane fractions reached a plateau even if the substrate concentration was 80 -fold the value of $\mathrm{K}_{\mathrm{m}}$. Both soluble and membrane fractions show excess substrate inhibition (Figure 2) with higher Vmax for soluble fraction (HSS extraction) (3.7 $\mu \mathrm{M} / \mathrm{mg} / \mathrm{min})$.

Table 1. Percent of common carp brain ChE activity inhibition by eserine and BW284C51at $1 \times 10^{-5} \mathrm{M}$

\begin{tabular}{lll}
\hline & \multicolumn{2}{l}{ Percent of activity inhibition } \\
\hline Extraction buffer & Eserine & BW284C51 \\
\hline LSS & 62.31 & 92.25 \\
HSS & 85.43 & 95.09 \\
DSS & 85.86 & 97.33 \\
\hline
\end{tabular}

A

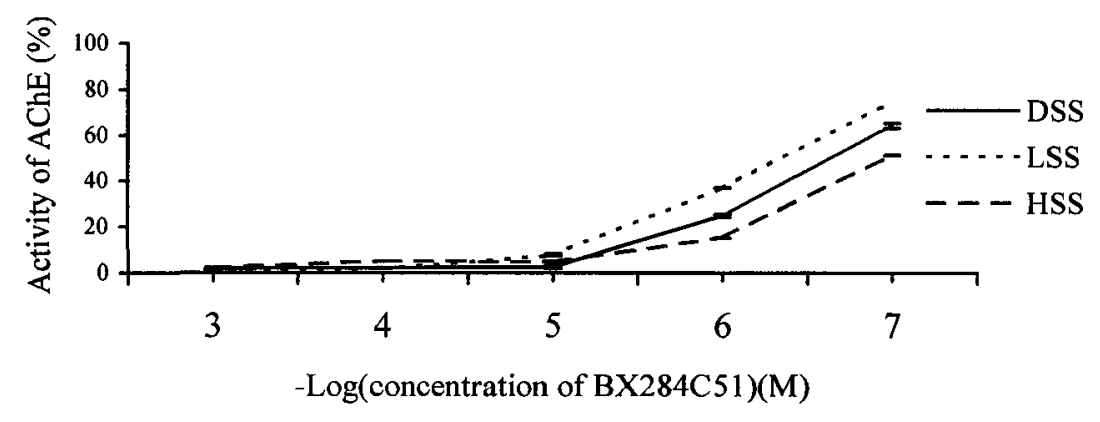

B

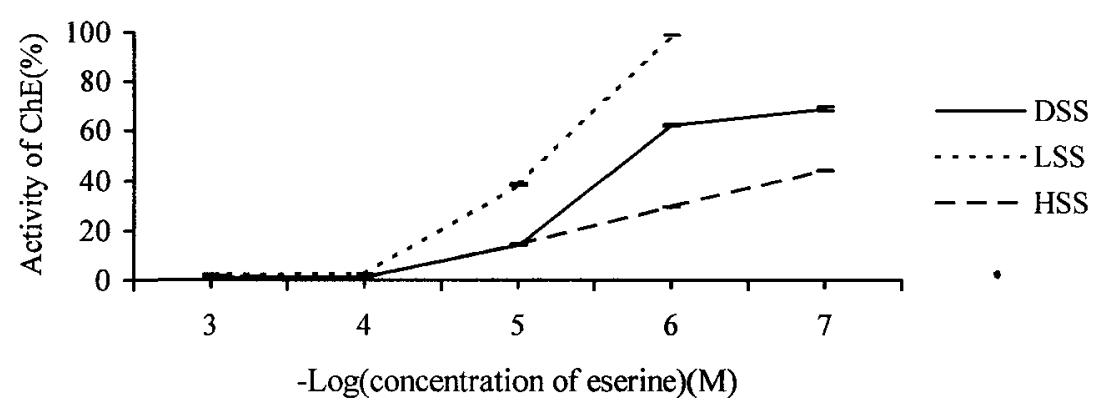

Figure 1. Inhibition of common carp brain ChE extracted with low salinity buffer (LSS), high salinity buffer (HSS) and high salinity buffer (HSS) with $2 \%$ of detergent Triton X-100 (DSS) by BW284C51 (A) and eserine (B). The remaining activity was determined after preincubation of cholinesterase with inhibitor for 2 min at $25^{\circ} \mathrm{C}$ and $\mathrm{pH} 8.5 . n=3$. 


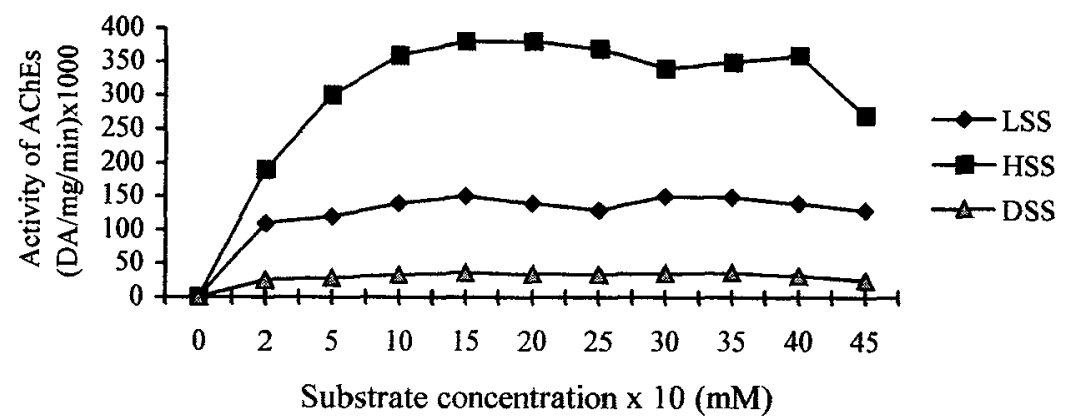

Figure 2. Effect of substrate concentration on the hydrolysis of acetylthiocholine chloride by common carp brain ChE extracted with low salinity buffer (LSS), high salinity buffer (HSS), high salinity buffer with $2 \%$ Triton X-100 (DSS) at the following condition : pH 8.5; temperature $25^{\circ} \mathrm{C}$ for $2 \mathrm{~min}$. Each point represents the mean of three replications.

Table 2. $V_{m}$ and $K_{m}$ determined by Lineweaver-Burk plot of $1 / v$ vs $1 / \mathrm{s}$ for ChE extract successively with low salinity buffer (LSS), high salinity buffer (HSS) and high salinity buffer with $2 \%$ Triton X-100 (DSS) hydrolysing ACh at $25^{\circ} \mathrm{C}$ and $\mathrm{pH} 8.5$.

\begin{tabular}{llll}
\hline Extraction buffer & $\mathrm{V}_{\max }(\mu \mathrm{M} / \mathrm{mg} / \mathrm{min})$ & $\mathrm{K}_{\mathrm{m}}(\mu \mathrm{M})$ & $\mathrm{V}_{\max } / \mathrm{K}_{\mathrm{m}}$ \\
\hline LSS & 1.40 & $5.7 \times 10^{-1}$ & 24.5 \\
HSS & 3.70 & $1.6 \times 10^{-1}$ & 23.1 \\
DSS & 0.34 & $6.8 \times 10^{-2}$ & 5.00
\end{tabular}

A

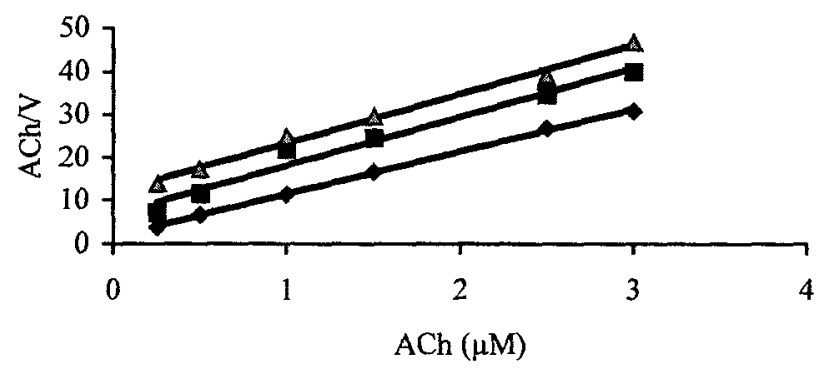

- AChE

- $\mathrm{AChE}+\mathrm{Cl}$

$\triangle \mathrm{AChE}+\mathrm{C} 2$

B

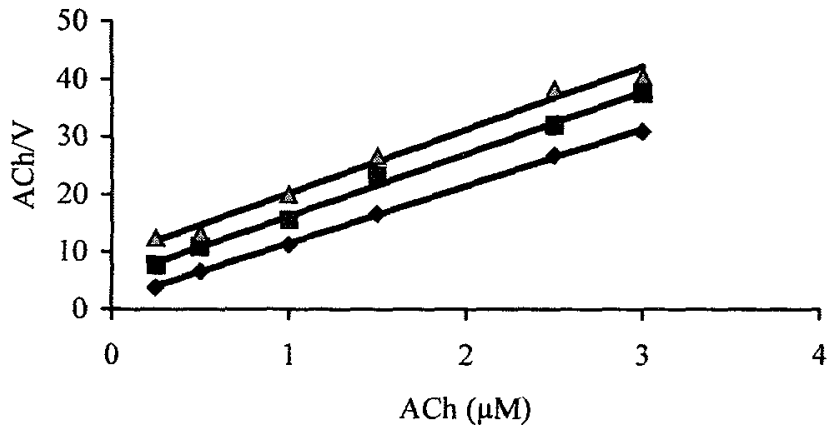

- $\mathrm{AChE}$

- $\mathrm{AChE}+\mathrm{CH} 1$

$\triangle \mathrm{AChE}+\mathrm{CH} 2$

Figure 3. Hanes-Woolf plot of [ACh] vs [ACh]/V for AChE extract with HSS inhibition by two concentrations of carbofuran (A) and two concentrations of chlorfenvinphos (B) (carbofuran. $\mathrm{Cl}=2 \times 10^{-7} \mathrm{M} ; \mathrm{C2}=4 \times 10^{-7} \mathrm{M}$ and chlorfenvinphos $\mathrm{CHl}=9 \times 10^{-6} \mathrm{M}$ and $\left.\mathrm{CH} 2=18 \times 10^{-6} \mathrm{M}\right)$. The activity was determined after AChE was incubated with fixed concentration of insecticides in the presence of substrate ACh with various concentrations at $25^{\circ} \mathrm{C}$; $\mathrm{pH}$ 8.5. Each point is based on the mean of three determinations. The parallel line indicated the competitive inhibition. 
The $\mathrm{K}_{\mathrm{m}}$ values are reported in Table 2. The greatest value was obtained with HSS fraction $\left(1.6 \times 10^{-1}\right.$ $\mu \mathrm{M})$. As revealed by Zhu and Brindley (1992) on Lygus hesperus Knight (Miridae, Hemiptera) the inhibitory specificity found in the common carp brain suggests that soluble and membrane bound fractions of the common carp brain ChE are "true" ChE with peripheral site.

The values of the $\mathrm{V}_{\max } / \mathrm{k}_{\mathrm{m}}$ ratio, a more significant parameter of the catalytic efficiency, showed clearly that soluble forms had better affinity for ACh than the membrane bound forms. The order of affinity toward ACh was LSS $>$ HSS $>$ DSS (Table 2). Previous studies conducted in vivo and in vitro in our laboratory have shown an inhibitory effect of chlorfenvinphos and carbofuran on carp brain cholinesterase (unpublished data).

The enzyme inhibitor can be competitive and able to combine with free enzyme that prevents substrate binding. As the inhibitor and the substrate have the same site, the $\mathrm{V}_{\max }$ remains unchanged. The non competitive inhibitors have no effect on the substrate binding so the $\mathrm{K}_{\mathrm{m}}$ remains unchanged (Segel 1975). The inhibition of carbofuran and chlorfenvinphos to the soluble acetylcholinesterase extract from the common carp brain is shown in Hanes- Woolf plot (Figure 3 A and B).

The results obtained with both carbofuran and chlorfenvinphos created nearly parallel lines. Both compounds did not alter $\mathrm{V}_{\max }$ value (indicated by unchanged slope) but altered the affinity of substrate binding to $\mathrm{AChE}$ (indicated by the increase in $\mathrm{K}_{\mathrm{m}}$ ). Our study indicated competitive inhibition by carbofuran and chlorfenvinphos, showing that all Cs and OPs compounds can effectively inhibit the activity of the common carp brain AChE.

If enzyme affinities can predict in vivo pattern of inhibition, there is great potential to use these affinities to predict pollution and environmental animal susceptibility. But it should be noted that cholinesterase activity can return to a normal level, if exposure to insecticides is discontinuous (Fleming and Grue 1981; Fleming 1981; Fossi et al. 1995). Until now little is known about recovery patterns or length of time required for complete recovery of carp brain AChE activity after exposure to insecticides. In this study, the recovery of the brain AChE activity after inhibition was performed on the HSS extract. After 96 hour exposure period to Birlan ${ }^{\circledR}$ (chlorfenvinphos) $(0.24 \mathrm{ppb})(\mathrm{OP})$ and Curater ${ }^{\circledR}$ (carbofuran) $(\mathrm{C})(3 \mathrm{ppb})$ no mortality occurred but the fishes treated with Birlan ${ }^{\circledR}$ (chlorfenvinphos) were unable to swim.

Fish brain AChE was extracted with HSS. (Percent of control group brain AChE activity). A large variability was found throughout the fish AChE activity for the fish treated with Birlan ${ }^{\circledR}$ (chlorfenvinphos) (Tukey multiple comparison $\mathrm{df}=: 5 \mathrm{P}<0.0001$ ). Fish treated with Curater ${ }^{\circledR}$ (carbofuran) and the control fish shows more uniform variation in the brain AChE activity (Anova $\mathrm{df}=$ $5, \mathrm{P}=0.045$ and 0.3 respectively). Birlan ${ }^{\circledR}$ (chlorfenvinphos) was more potent inhibitor than Curater ${ }^{\circledR}$ (carbofuran) in vivo. The residual activity observed at the presence of Birlan ${ }^{\circledR}$ (chlorfenvinphos) was $11.87 \%$ (Table 3).

Table 3. Recovery of brain AChE activity in common carp brain exposed to Curater $\AA$ and Birlan ${ }^{\circledR}$. Specific activity $+S E\left(\mathrm{mM} / \mathrm{min} / \mathrm{mg}\right.$ of protein) $\times 10^{-4 \mathrm{~s}}$

\begin{tabular}{|c|c|c|c|c|c|c|}
\hline & & $\begin{array}{l}\text { Daypost- } \\
\text { exposure }\end{array}$ & & & & \\
\hline & 0 & 1 & 2 & 5 & 8 & 15 \\
\hline Control & $1.6 \pm 1.0$ & $1.6 \pm 0.2$ & $1.2 \pm 0.19$ & $1.2 \pm 1.6$ & $1.8 \pm 0.4$ & $1.9 \pm 0.4$ \\
\hline \multirow[t]{2}{*}{ Curater ${ }^{\circledR}$} & $2 \pm 0.9$ & $3 \pm 0.06$ & $2.5 \pm 0.1$ & $1.9 \pm 0.4$ & $3.1 \pm 0.6$ & $2.5 \pm 0.3$ \\
\hline & $(120)$ & $(182.2)$ & $(195.2)$ & $(155.2)$ & $(174.6)$ & $(133.4)$ \\
\hline \multirow[t]{2}{*}{ Birlan ${ }^{\circledR}$} & $0.19 \pm 0.03$ & $0.3 \pm 0.07$ & $0.58 \pm 0.07$ & $0.8 \pm 0.1$ & $1.4 \pm 0.3$ & $2.5 \pm 1.4$ \\
\hline & (11.87) & $(17.8)$ & $(45.6)$ & $(65.2)$ & $(80.9)$ & (132.9) \\
\hline
\end{tabular}


Table 4. Results of regression analysis of recovery rate of the brain AChE (HSS extract) activity following exposure to Birlan ${ }^{\circledR}$ and Curater ${ }^{\circledR}$ for $96 \mathrm{hr}$

Regression line of AChE activity vs day

$\begin{array}{llc} & \mathrm{Y}=\mathrm{a} \times 10^{4}+\mathrm{b} \times 10^{4} & \\ \text { Control } & 13.6 & 0.377 \\ \text { Curater® } & 26.1 & -0.023 \\ \text { Birlan }{ }^{\circledR} & 2.16 & 1.17\end{array}$

The results of the experiment showed that brain AChE activity was almost completely recovered within one day after exposure to carbofuran and 15 days after exposure to chlorfenvinphos. There is significant difference in the patterns of recovery of Curater ${ }^{\circledR}$ (carbofuran) treated and Birlan ${ }^{\circledR}$ (chlorfenvinphos) treated fish (Table 3). Although recovery data are linear and used the model $\mathrm{Y}=\mathrm{a}+$ bx where $\mathrm{x}$ is the days after exposure, it did not take the same time for fish treated with $\mathrm{C}$ and OP. (Table 4).

The recovery of the brain AChE took only a few hours for the Curater® (carbofuran) treated fish because this insecticide is a reversible inhibitor. There is a significant difference between the first measurement and the other (tukey multiple comparison $\mathrm{q}=0.76 ; \mathrm{P}<0.05$ ). In the case of Birlan ${ }^{\circledR}$ (chlorfenvinphos) treated fish, recovery is due to dephosphorilation, decarbamilation and de novo synthesis. The inhibition rate does not change within the first two days after the exposure to Birlan ${ }^{\circledR}$ (chlorfenvinphos) (tukey multiple comparison $\mathrm{df}=5 ; \mathrm{q}=2.3 ; \mathrm{P}<0.05$ ). The significant difference with the inhibition rate appears after 5 days (tukey multiple comparison $\mathrm{df}=5 ; \mathrm{q}=3.6 ; \mathrm{P}<0.05$ ).

Using inhibition of carp brain AChE activity as the criteria for diagnosing the anti-cholinesterase exposure, it appears that a diagnosis of such exposure could be made in a few hours for $\mathrm{C}$ poisoned fish but this period must be extended to 2 weeks when fishes are poisoned with OP in our conditions. These results are in agreement with those of (Kuhn and Streit 1994) on invertebrate. However, the time was longer than that observed in maillard by Fleming and Grue, (1981) and shorter than that observed in grackle.

Acknowledgments: The authors thanks Arnaud, L.; Assié, L.K.; Vroh Bi; I. Zoro Bi, I. for their helpful comment on the manuscript and Mrs Moremane (Bibliotheque centrale, FSAGX) for checking the english style. A scholarship to the first author was provided by the Scientific Research Ministry of Cote d'ivoire.

\section{References}

Augustisson KB, Nachmanshon D (1949) Distinction between acetylcholinesterase and other choline ester-splitting enzymes. Science 110:98-99

Bastos VLFC, Bastos, C, Lima, JS, Faria, MCV (1991) Brain acetylcholinesterases as an in vitro detector of organophosphorus and carbamate insecticides in water. Wat Res 25: 835-840

Billard R (1995). La biologie des cyprinydae. In: R Billard (ed) Les carpes. Biologie et ecologie. INRA Paris, p. 1-21

Bocquene G, Bellanger C, Caudiou Y, Galgani F (1995) Joint action of combination pollutants on the acetylcholinesterase activity of several marine species. Environ Toxicol Chem 4: 266-279

Bon S, Vigny M, Massoulie J (1979) Assymetric and globular forms of acetylcholinesterase in mammals and birds. Proc Natl Acad Sci USA 76: 2546-2550

Castillo LE, De La Cruz E, Rupert C (1997) Ecotoxicology and pesticides in tropical aquatic ecosystems of central America. Environ Toxicol Chem 16:41-51

Coppage DL, Mathews E (1974) Short-term effects of organophosphate pesticides on cholinesterase of estuarine fishes and pink shrimp. Bull Environ Contam Toxicol 11: 483-487 
Dagnelie P (1975). Theorie et methodes statistiques. Presse Agronomique de Gembloux, Gembloux, Belgium Davison AN (1955) Return of cholinesterase activity in the rat after inhibition by organophosphorus compounds. Biochem J 60: 339-346

Ellman GL, Courtney KD, Andres Jr V, Featherstone RM (1961) A new and rapid colorimetric determination of acetylcholinestrase activity. Biochem Pharmacol 7: 88-95

Fleming JW, Grue EC (1981) Recovery of cholinesterase activity in five avian species exposed to dicrotophos an organophosphorus pesticide. Pest Biochem Physiol 16: 129-135

Fleming WJ (1981) Recovery of brain and plasma cholinesterase activities in Duckling exposed to organophosphorus pesticides. Arch Environ Toxicol 10:215-229

Fossi MC, Sanchez-Hernandez JC, Diaz-Diaz R, Lari L, Garcia-Hernandez L Gaggi C (1995) The lizard Galliota galloti as a bioindicator of organophosphorus contamination in the canary islands. Environ Poll 87: 289-294

Harel M, Susman JL, Krejci E, Bon S, Chanal P, Massoulie J, Silman I (1992) Conversion of acetylcholinesterase to butyrylcholinesterase: Modeling and mutagenesis. Proc Natl Acad Sci USA 89: 10827-10831

Haubruge E, Toutant JP (1997) L'acetylcholinesterase du systeme olfatif de la carpe Cyprinus carpio L. (POISSON: CYPRINIDEA): forme moleculaire et inhibition in vivo et in vitro par le carbofuran. Belg J Zool 127: 63-73

Kuhn, K, Streit, B (1994) Detecting sublethal effect of organophosphates by measuring acetylcholinesterase activity in Gammarus. Bull Environ Contam Toxicol 53: 398-404

Lowry OH, Rosebroucgh NJ, Farr AL, Randall R (1951) Protein measurement with folin phenol reagent. J Biol Chem 193: 193-265

Massoulie J, Bon S (1982) The molecular form of cholinesterase and acetycholinesterase in vertebrates. Ann Rev Neurosc 5: 57-106

Segel IH (1975). Biochemical calculations. John Wiley \& Sons, Davis Sharma B, Gopal K, Khana YP (1993) Interaction of carbaryl with acetylcholinesterase of the teleost, Clarias batrachus.

Toxicol Environ Chem39: 147-152

Sine J-P, Toutant J-P, Weigel P, Colas B (1992) Amphiphilic forms of butyrylcholinesterase in mucosal cells of rat intestine. Biochemistry 31: 10893-10900

Sylver A (1974). The biology of cholinesterase. In: AT Neuberger, E.L. (ed) Frontiers of biology Amsterdam Szabo A, Nemcsok J, Asztalos B, Rakonczay Z, Kasa P, Le HH (1992) The effect of pesticide on carp( Cyprinus carpio L.) Acetylcholinesterase and its biochemical characterisation. Ecotox Environ Saf 23: 39-45

Szegletes T, Balint T, Szegletes Z, Nemcsok J (1995) Changes caused by methidathion in activity and distribution of molecular forms of carp \{Cyprinus carpio L.) AChE. Pest Biochem Physiol 52: 71-79

Toutant JP, Massoulie J, Bon S (1985) Polymorphism of pseudocholinesterase in Torpedo marmorata tissues: Comparative study of the catalytic and molecular properties of this enzyme with acetylcholinesterase. J Neurochem 44: 580-591

Vigny M, Gisiger G, Massoulie J (1978) "Nonspecific" cholinesterase and acetylcholinesterase in rat tissues: molecular forms, structural and catalytic properties, and significance of the two enzyme systems. Proc Natl Acad Sci USA 75: 2588-2592

Westlake GE, Bunyan JP, Martin AD, Stanley D, Steed LC (1981a) Carbamate poisoning. Effects of selected carbamates pesticides on plasma enzymes and brain esterase of Japanese quail (Coturnix 
Published in : Bulletin of environmental contamination and toxicology (1999), vol.62, iss. 6, pp. 731-742 Status : Postprint (Author's version)

coturnix japonica). J Agric Food Chem 29: 779-785

Westlake GE, Bunyan JP, Martin AD, Stanley D, Steed LC (1981b) Organophosphate poisoning. Effects of selected carbamates pesticides on plasma enzymes and brain esterase of Japanese quail \{Coturnix coturnix japonica). J Agric Food Chem 29: 772-778

Zhu KY, Brindley WA (1992) Enzymological and inhibitory properties of acetycholinesterase purified from Lygus herperus KNIGHT(Hemiptera: Muridea). Insect Biochem Mol Biol 22: 245-251 